\title{
Use of drugs in Argentina: A worrying issue.
}

\section{Enrique M. Rodríguez*}

Department of Biodiversity and Experimental Biology, FCEN, Institute of Biodiversity, Experimental and Applied Biology (IBBEA), CONICET-UBA, University of Buenos Aires, Argentina

Accepted on October 13, 2017

\section{Introduction}

In Argentina, the use of drugs has markedly increased since the beginning of the new millennium. For instance, during the period 2007-2009, the consumption of psychotropic drugs was well above world average, Argentina appearing as the second American country, just behind the USA. A peak in the use of antidepressants was noted in 2001, in correlation with the economic crisis installed in the country. Present data indicate that $18 \%$ of the population between 12 and 65 years old consume tranquilizers or anxiolytics [1]. In addition to psychotropics, the increased consumption of several other drugs, such as analgesics, anti-inflammatories, and antibiotics is equally alarming.

According to public statistics, $82 \%$ of argentine adults often consume over the counter drugs, while $99 \%$ of surveyed people have admitted to have been eventually self-medicated. Antibiotics and anti-flu drugs are leading the list of drugs used for self-medication, also including analgesics and antiinflammatories. Paradoxically, there is a 1969 law establishing the sale of antibiotics under filed prescription. However, there are no effective controls on that legislation. Moreover, in 2009, a new law prohibited the exposition of over the counter drugs in free-access display racks, being a pharmaceutical employee the only person authorized to sell such drugs; unfortunately, once again, this was an empty regulation.

Use and abuse of drugs by human population has ecotoxicological consequences as well, specially taking into account that treatment plants are inefficient in cleaning most drugs. A study recently made in a variety of urbanized areas in Argentina [2] showed detectable levels of pharmaceuticals in wastewaters from all sampled sites; for instance, levels of ibuprofen as high as $13.0 \mu \mathrm{g} / \mathrm{L}$ were found, together with other drugs such as carbamazepine, atenolol, and diclofenac at levels ranging between 0.2 and $1.7 \mu \mathrm{g} / \mathrm{L}$. Moreover, in rivers of the Pampa, a region mainly devoted to farming, most samples showed detectable levels of several of the drugs above mentioned: $9.7, \quad 0.63$ and $0.55 \mu \mathrm{g} / \mathrm{L}$ of ibuprofen, carbamazepine and atenolol, respectively [3]. A similar picture takes place at the Suquía River [4], which receives the effluents from Córdoba City treatment plants.

Several studies designed to assess the harmful effects of these pollutants on the local aquatic fauna are currently underway. For instance, a recently published article [5] reports an endocrine disruption in cichlid fish exposed to fluoxetine, which was able to alter the pituitary level of luteinizing hormone. The capacity to accumulate detectable levels of carbamazepine and atenolol was also reported in other autochthon fish species [4]. The potential risk of some antiinflamamatory drugs to the reproductive success of estuarine crabs are currently under evaluation by the author of this editorial. Several antiobiotics of common use in cattle and poultry veterinary medicine have shown to affect both growth and development in amphibian larvae, at environmental concentrations [6]. Similarly to the situation mentioned above for the consumption of drugs by human population, there is no regulation in Argentina for processing the wastes produced by feedlots; therefore, the environmental impact of drugs for veterinary use is expected to remain high.

\section{References}

1. SEDRONAR. Una mirada específica sobre la problemática del consumo de psicofármacos en Argentina 2012. Presidencia de la Nación. Buenos Aires, Argentina. 2013;p: 92.

2. Elorriaga Y, Marino DJ, Carriquiriborde P, et al. Human pharmaceuticals in wastewaters from urbanized areas of Argentina. Bull Environ Contam Toxicol. 2012;90(4): 397-400.

3. Elorriaga Y, Marino DJ, Carriquiriborde P, et al. Screening of pharmaceuticals in surface water bodies of the Pampas region of Argentina. Int $\mathrm{J}$ Environ Res Public Health. 2013;6(4):330-339.

4. Valdés ME, Amé MV, Bistoni MA, et al. Occurrence and bioaccumulation of pharmaceuticals in a fish species inhabiting the Suquía River basin (Córdoba, Argentina). Sci Total Environ. 2014;472:389-396.

5. Dorelle LS, Da Cuña RH, Rey Vázquez G, et al. The SSRI fluoxetine exhibits mild effects on the reproductive axis in the cichlid fish Cichlasoma dimerus (Teleostei, Cichliformes). Chemosphere. 2017;171:370-378.

6. Peltzer PM, Lajmanovich RC, Attademo AM, et al. Ecotoxicity of veterinary enrofloxacin and ciprofloxacin antibiotics onanuran amphibian larvae. Environ Toxicol Phar. 2017;51:114-123.

\section{*Correspondence to:}

Enrique M. Rodríguez

Department of Biodiversity and Experimental Biology

FCEN, Institute of Biodiversity, Experimental and Applied Biology (IBBEA)

CONICET-UBA

University of Buenos Aires

Argentina

E-mail: enrique@bg.fcen.uba.ar 